\section{The study of energy consumption in the dimension stone cutting process}

The Mining-Geology-Petroleum Engineering Bulletin UDC: 679.8

DOI: $10.17794 / \mathrm{rgn} .2018 .4 .6$

\section{Original scientific paper}

\author{
Reza Mikaeil '; Babak Sohrabian ${ }^{2}$; Mohammad Ataei ${ }^{3}$ \\ ${ }^{1}$ Department of Mining and Materials Engineering, Urmia University of Technology, Urmia, Iran. \\ ${ }^{2}$ Department of Mining and Materials Engineering, Urmia University of Technology, Urmia, Iran. \\ ${ }^{3}$ Faculty of Mining, Petroleum \& Geophysics, Shahrood University of Technology, Shahrood, Iran.
}

\begin{abstract}
In the dimension stone industry, predicting energy consumption in the rock cutting process and examining its relationship with machining parameters are among the most important steps to achieving the optimum conditions in terms of energy consumption. A laboratory scale cutting machine with changing machining parameters was made and its energy consumption was evaluated through statistical analysis. Tests were carried out on seven carbonate rock samples under different operating conditions at different depths of cut, feed rates and peripheral speeds. Finally, an energy consumption model was obtained through statistical studies using SPSS software. The $t$ and $F$ tests were used to validate the model and to control each of the independent variables. To see the prediction capability of the derived model, the scatter diagram of the observed and estimated values was plotted. The results showed that the points are very close to the 1:1 diagonal straight line. It concluded that the developed model has a high degree of accuracy with a high correlation between the predicted and the observed values. Due to its high accuracy, the proposed model can be used in the calculation of energy consumption under various operating parameters.
\end{abstract}

\title{
Keywords
}

Energy consumption; feed rate; peripheral speed; depth of cut; SPSS; Dimension stone

\section{Introduction}

Improving the efficiency of energy consumers for the proper use of energy resources is one of the most important issues of recent studies. The need for energy is rapidly increasing so that all industries and sectors are looking for its minimization. In the stone cutting process, adverse environmental effects due to poor technical management and inefficient use of energy brings about the need for energy optimization and carrying out projects in this regard. To tackle the problems, the first step is to acquire a deep understanding of the process and its effective parameters. The cutting process is an abrasive operation, which can be summarized in two steps. In the first step, the diamond segments move on the cutting surface, which results in the formation of a stone chip due to the penetration of the diamond grains into the rock. During this process, through the scraping and breaking of the cutting surface, the diamond grains form a chip and create a new surface for the next grains. In the cutting process, the mechanical interaction between the instruments and the stone generates a cutting force which is mainly caused by factors such as the elastic and

Corresponding author: Babak Sohrabian

babak_sohrabian@uut.ac.ir plastic deformation of stone, friction between the diamond and the matrix and the stone and the cutting chips. Figure 1 shows a schematic view of a diamond grain and its interaction forces with the scratched surface of the stone (Tonshoff et al., 2002).

These changeable forces together with the posts and heights at the workpiece surface, discontinuous thickness of the chips, the chips cracking and the layering, the friction between the surfaces change the cutting conditions. Like other machining processes, factors affecting the cutting performance can be evaluated in two main sections:

(1) Workpiece (stone) related studies: In this context, several experimental models and several sorted samples are presented to anticipate the cutting ability according to the mechanical and physical characteristics (valid references).

(2) Cutting characteristics (machine, cutter and cutting method): Cutting plot characteristics include workpiece feed rate (Fr), peripheral speed (Ps), depth of cut (Dc), disk (B), segment (S) and the cutting method (M). The best cutting performance occurs by choosing a suitable feed rate, peripheral speed, cutting depth, diamond tools and an appropriate cutting method. Some studies, carried out in this field, are presented in Table 1. 


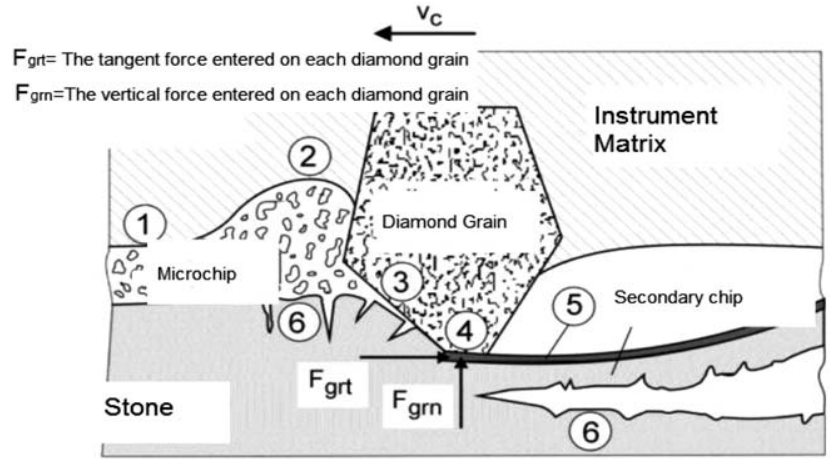

1.Friction zone between microchip and instrument matrix

2.Worn zone by microchips and chips

3.Primary brushing area

4.Friction zone between stone and diamond grain

5.Plastic deformation zone

6.Elastic deformation zone

Figure 1: The interaction forces between the diamond and the scratched surface of the stone

(from Tonshoff et al., 2002)

Table 1: Operational cutting parameters studied by various researchers.

\begin{tabular}{|l|c|c|c|c|c|c|}
\hline \multirow{2}{*}{ Researcher } & \multicolumn{3}{|c|}{$\begin{array}{c}\text { Sawing } \\
\text { mode }\end{array}$} & \multicolumn{2}{c|}{$\begin{array}{c}\text { Operational } \\
\text { properties }\end{array}$} \\
\hline & B & S & M & Dc & Fr & Ps \\
\hline Ertingshausen, 1985 & & & $\bullet$ & $\bullet$ & & \\
\hline Jenning and Wright, 1989 & $\bullet$ & $\bullet$ & $\bullet$ & $\bullet$ & $\bullet$ & $\bullet$ \\
\hline Konstanty, 1991 & & $\bullet$ & & & & \\
\hline Xipeng Xu, 1999 & & $\bullet$ & & $\bullet$ & $\bullet$ & \\
\hline Clausen and Wang, 1996 & & $\bullet$ & & & & \\
\hline Xipeng Xu et al., 2001 & & & & $\bullet$ & $\bullet$ & $\bullet$ \\
\hline Konstanty, 2002 & & & $\bullet$ & & & \\
\hline Tonshoff et al., 2002 & & $\bullet$ & $\bullet$ & $\bullet$ & $\bullet$ & $\bullet$ \\
\hline Xipeng Xu et al., 2003 & & & $\bullet$ & $\bullet$ & $\bullet$ & $\bullet$ \\
\hline Engels, 2003 & & $\bullet$ & & $\bullet$ & $\bullet$ & $\bullet$ \\
\hline Ersoy et al., 2004 & & & & $\bullet$ & $\bullet$ & $\bullet$ \\
\hline Kahraman et al., 2004 & $\bullet$ & & & $\bullet$ & $\bullet$ & $\bullet$ \\
\hline Gunaydin et al., 2004 & $\bullet$ & & & & $\bullet$ & $\bullet$ \\
\hline Buyuksagis and Goktan, 2005 & & & & $\bullet$ & $\bullet$ & \\
\hline Buyuksagis, 2007 & & & $\bullet$ & $\bullet$ & $\bullet$ & \\
\hline Polini and Turchetta, 2007 & & & & $\bullet$ & $\bullet$ & \\
\hline Atici and Ersoy, 2009 & & & & $\bullet$ & $\bullet$ & \\
\hline Mikaeil et al., 2011a & & & & $\bullet$ & $\bullet$ & \\
\hline Mikaeil et al., 2011b & & & & $\bullet$ & $\bullet$ & \\
\hline Mikaeil et al., 2011c & & & & $\bullet$ & $\bullet$ & \\
\hline Mikaeil et al., 2014 & & & & $\bullet$ & $\bullet$ & \\
\hline Mikaeil et al., 2016 & & & & $\bullet$ & $\bullet$ & \\
\hline
\end{tabular}

$\mathrm{F}_{\mathrm{r}}$ : Feed rate, $\mathrm{P}_{\mathrm{s}}$ : Peripheral speed, $\mathrm{D}_{\mathrm{c}}$ : Depth of cut, B: Disk, S: Segment, M: Sawing type

This article examines the effects of machining parameters on the energy consumption of cutting processes. Laboratory-scale equipment was designed and fabricated to carry out tests on 7 building stone samples. Then, statistical studies were done on the experimental results and a model was introduced for predicting the energy consumption. Finally, the results are presented and a conclusion is given.

\section{Laboratory studies}

\subsection{Designing and fabrication of a cutting machine}

Laboratory studies were implemented in order to examine the relationship of machining parameters and energy consumption. For this purpose, a cutting machine was installed and set up, cutting tools and energy consumption measuring equipment were provided and suitable stone pieces to be tested were prepared. Figure 2 shows an overview of the provided test devices. Some properties of the sawing machine, the sawing tools and the workpiece used in the study are presented in Table 2. All cuttings were done in a compatible mode. In a compatible cut, the advancement and the rotation are in the same direction. In all experiments, water was used as a coolant.

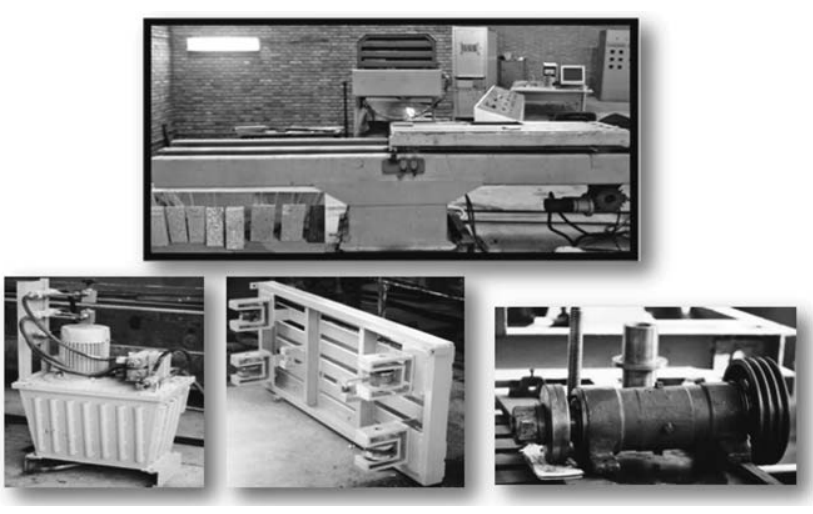

Figure 2: The cutting machine

Table 2: Properties of the machine, the tools and the workpiece used in the study

\begin{tabular}{|c|c|}
\hline Tools & Properties \\
\hline $\begin{array}{l}\text { Sawing } \\
\text { machine }\end{array}$ & $\begin{array}{l}\text { 7.5 KW main spindle engine } \\
\text { Hydraulic unit: to set up the thrusters and } \\
\text { thruster motors } \\
\text { Power board: to measure the feed rate }\end{array}$ \\
\hline $\begin{array}{l}\text { Sawing } \\
\text { tool }\end{array}$ & $\begin{array}{l}\text { Disk diameter: } 41 \mathrm{~cm} \\
\text { Disk thickness: } 2.7 \mathrm{~mm} \\
\text { Segment properties: number }(28), \\
3 \times 10 \times 40 \\
\text { Diamond grain properties: octagonal } \\
\text { crystal with } 30 / 40 \text { mesh } \\
\text { and } 25 \%-35 \% \text { concentration } \\
\end{array}$ \\
\hline $\begin{array}{l}\text { Ampere } \\
\text { meter }\end{array}$ & Accuracy: 0.05 Ampere \\
\hline Workpiece & Carbonate rock: Azarshahr red travertine \\
\hline
\end{tabular}




\subsection{Machining parameters}

All the machining parameters such as the feed rate, the cutting depth and the peripheral speed are adjustable and controllable. The feed rate (Fr) was measured by a hydraulic system and an electronic counter during the

Table 3: Energy consumption in cutting trials

\begin{tabular}{|c|c|c|c|c|}
\hline \multicolumn{3}{|c|}{ Machining parameters } & \multicolumn{2}{|c|}{ Energy consumption } \\
\hline Dc (mm) & $\operatorname{Fr}(\mathrm{cm} / \mathrm{min})$ & I (A) & $\mathbf{E}(\mathbf{W h})$ & $\mathrm{SE}\left(\mathrm{Wh} / \mathrm{cm}^{2}\right)$ \\
\hline 15 & 100 & 6.5 & 950 & 16.47 \\
\hline 15 & 200 & 6.9 & 1102 & 8.74 \\
\hline 15 & 300 & 8 & 1520 & 6.76 \\
\hline 15 & 400 & 8.3 & 1634 & 5.26 \\
\hline 19 & 100 & 6.7 & 1026 & 13.40 \\
\hline 19 & 200 & 7.1 & 1178 & 7.10 \\
\hline 19 & 300 & 8.6 & 1748 & 5.73 \\
\hline 19 & 400 & 9.5 & 2090 & 4.75 \\
\hline 22 & 100 & 6.8 & 1064 & 11.75 \\
\hline 22 & 200 & 7.5 & 1330 & 6.48 \\
\hline 22 & 300 & 9.2 & 1976 & 5.30 \\
\hline 22 & 400 & 10.5 & 2470 & 4.53 \\
\hline 25 & 100 & 7.1 & 1178 & 10.79 \\
\hline 25 & 200 & 7.8 & 1444 & 5.93 \\
\hline 25 & 300 & 9.9 & 2242 & 5.02 \\
\hline 25 & 400 & 12 & 3040 & 4.56 \\
\hline 30 & 100 & 7.1 & 1178 & 8.99 \\
\hline 30 & 200 & 8.1 & 1558 & 5.13 \\
\hline 30 & 300 & 10.5 & 2470 & 4.43 \\
\hline 30 & 400 & 14.5 & 3990 & 4.59 \\
\hline 35 & 100 & 7.5 & 1330 & 8.14 \\
\hline 35 & 200 & 9.5 & 2090 & 5.16 \\
\hline 35 & 300 & 12 & 3040 & 4.34 \\
\hline 35 & 400 & 16 & 4560 & 4.34 \\
\hline
\end{tabular}

experiment. Feed rate is studied as one of the operation parameters.

The depth of cut (Dc) was created by a vertical ride mechanism in the system. In this paper, cutting depths of 15, 22, 30 and $35 \mathrm{~mm}$ were studied.

The peripheral speed (Ps) was created by a $7.5 \mathrm{KW}$ electromotor with a maximum rotation rate of 2800 RPM. This movement is transmitted to the spindle axis in four different proportions using a belt and torque mechanism. The number of the spindle rotations is adjustable to three quantities. These experiments were performed at rotational speeds of 1540, 1770 and $2550 \mathrm{rpm}$. The speed was controlled by changing the engine's torque and the transmission ratio of the engine to the spindle. Measured data such as current consumption (I), energy consumption (E) and specific energy consumption (SE) at $1770 \mathrm{rpm}$ peripheral speed are presented in Table 3.

\section{The relationship between energy consumption and the operation parameters}

The relationship between energy consumption and specific energy consumption (as performance results) and operational properties were analysed. At each stage of the experiment, Azarshahr travertine pieces were fixed on a machine table and then cut off. In order to reduce the measurement errors, tests were performed several times. Then, the results of 48 experiments were recorded for further evaluation. During the test, by fixing the number of the spindle's rotations to 1770 RPM, which is proportional to the speed of disk rotation, changes in energy consumption were studied by modifying the cutting depth and the progress rate. Finally, the
Figure 3: Energy consumption changes to depth of cut for different feed rates at $1770 \mathrm{rpm}$ peripheral speed

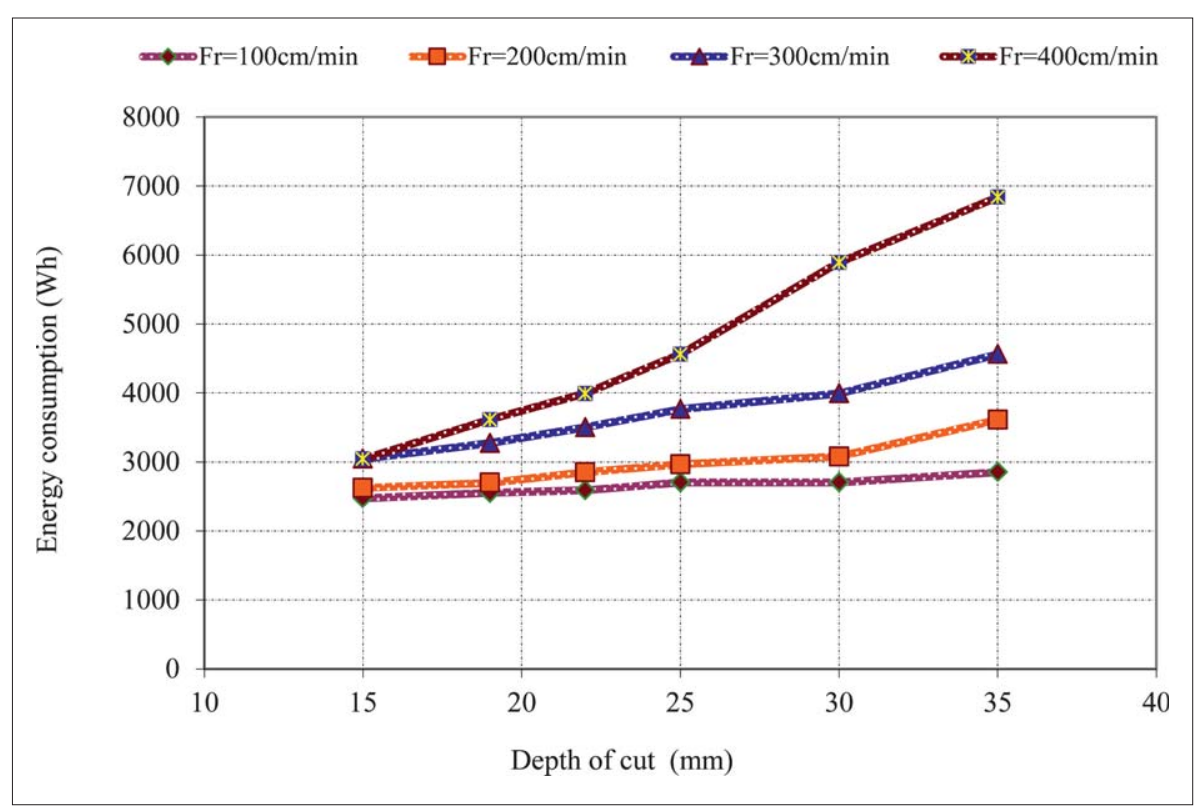




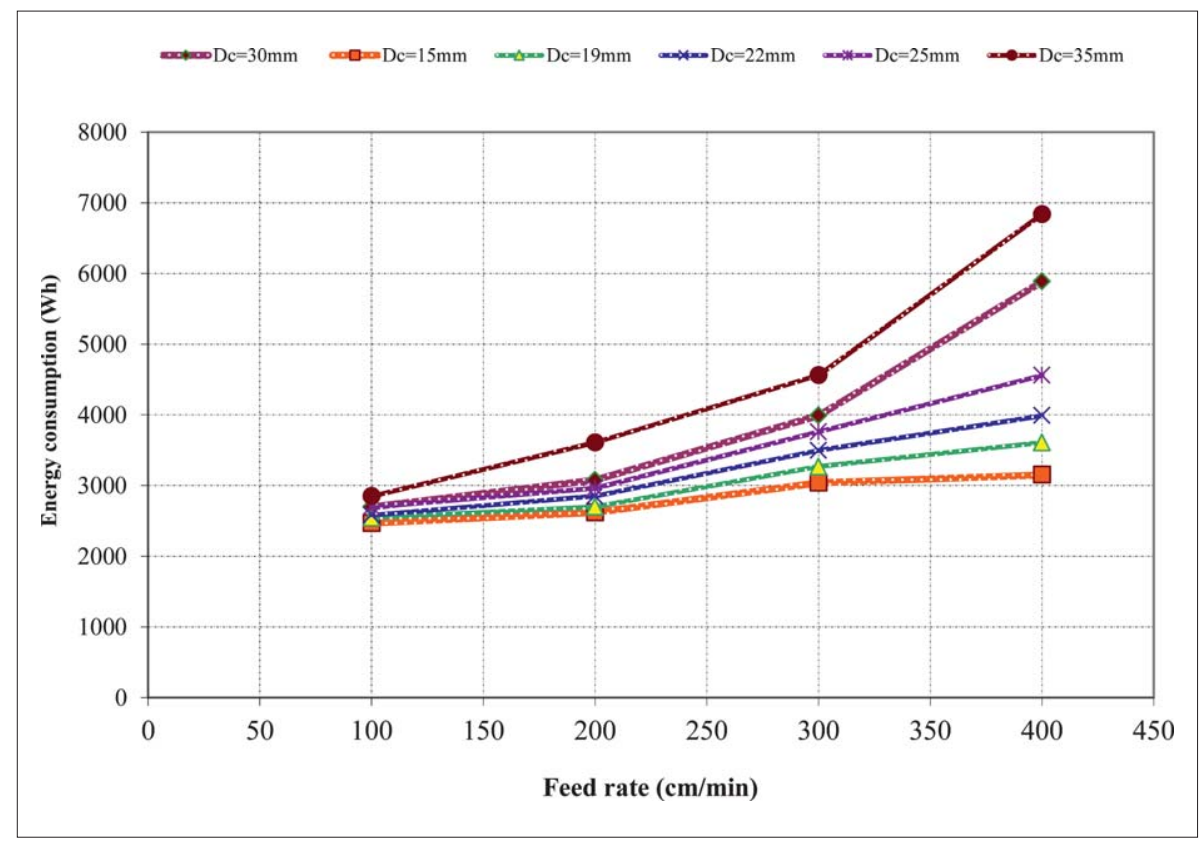

Figure 4: Energy consumption changes to feed rate for different depths of cut at $1770 \mathrm{rpm}$ peripheral speed

consumption rate was recorded at different feed rates and cutting depths. Graphs of Figures 3 and $\mathbf{4}$ respectively show energy consumption versus the cutting depth and the feed rate. At a constant peripheral speed, the energy consumption increases by an increase in the cutting depth or in the feed rate. While the slopes of the graphs increase gradually for all of them, the changes are much more noticeable for higher Fr values.

The reason for this increase can be due to the load pressure on the machine during cutting process. Under the same production conditions, the specific energy decreases as the cutting depth and the feed rate increase (see Figures 5 and 6). The reason can be searched in the chip formation mechanism. The cutting thickness has a direct relation with the speed of cutting and the cutting depth. In the other words, diamond grain penetration depth and the thickness of the swarf increase with an increase in the feed rate. An increased depth of the diamond's penetration causes an increase in the forces and tensions that enter the rock, which results in the formation and growth of lateral and radial cracks. The formation and expansion of these cracks in the rock causes the appearance of the secondary swarf. Deep penetration of diamonds increases the percentage of secondary chips to the point that a large volume of cuttings is of secondary chip type. In general, lateral cracks and the secondary chips make the swarf removal process easier and reduce the cutting forces.

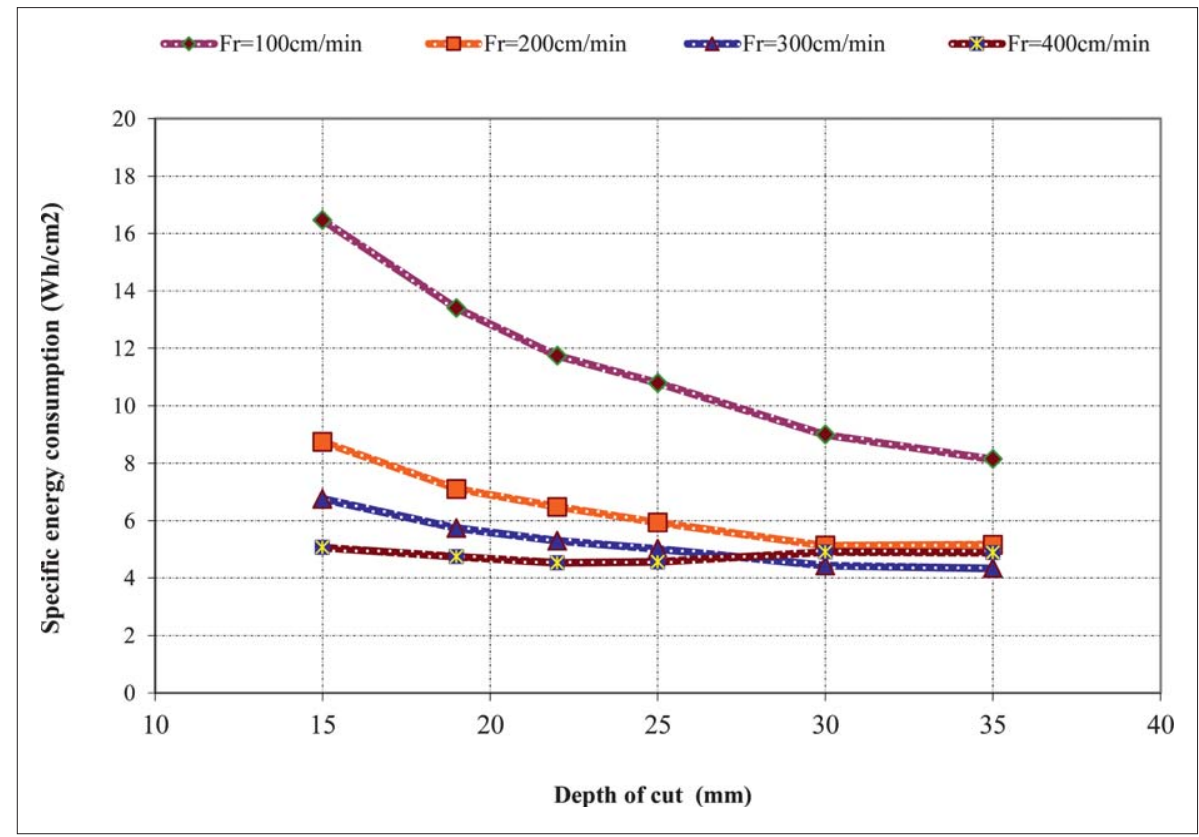

Figure 5: Specific energy consumption changes to depth of cut changes for different feed rates at 1770 rpm peripheral speed 
Figure 6: Specific energy consumption changes to feed rate changes for different depths of cut at 1770 rpm peripheral speed

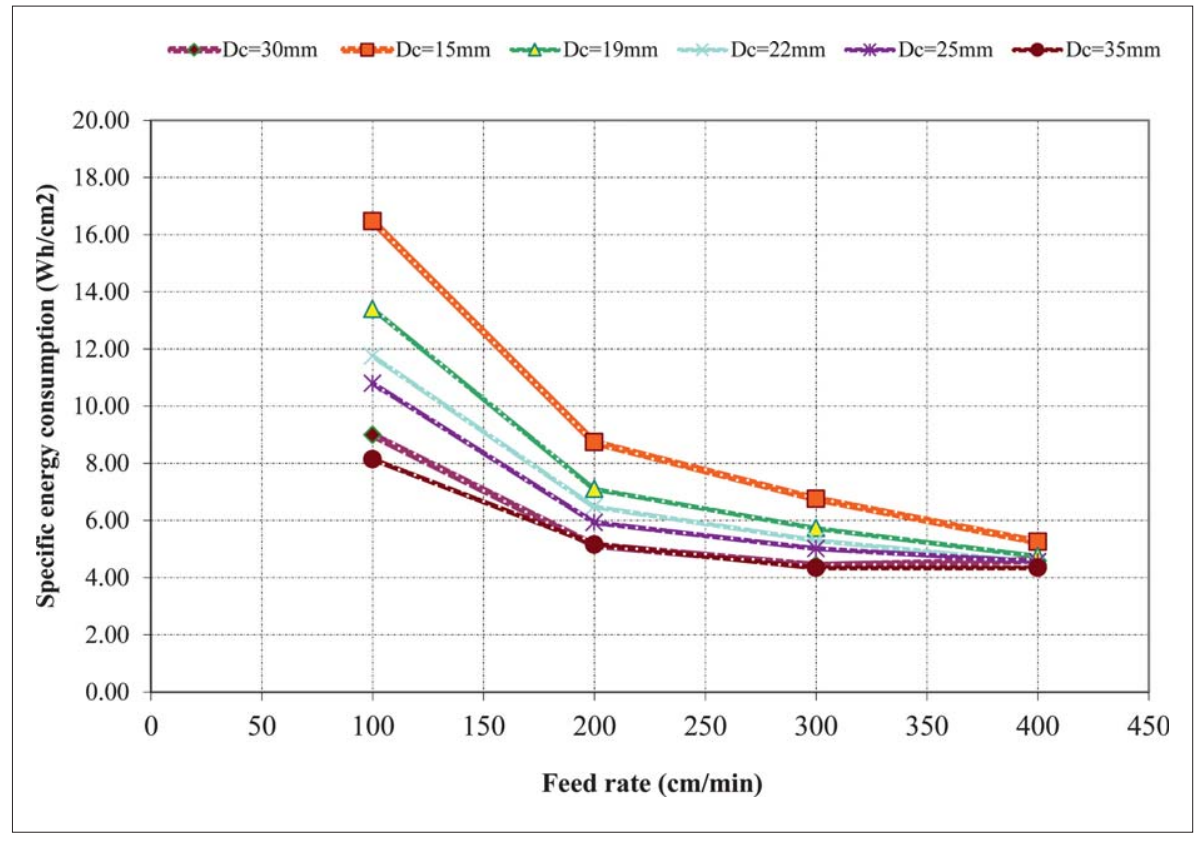

\section{Statistical studies}

In order to study the relationship of the operating parameters and the energy consumption, statistical analysis was carried out using SPSS software and a model was introduced. In order to increase the accuracy and the coverage of this model, 7 carbonate rock samples collected from Zolfaghar marble, Golsang marble, Azarshahr travertine, Hajiabad travertine, Darebokhari travertine, Salsali marble and Haftoman marble were tested and the results were studied at different operating conditions. The multivariate analysis using more than 120 test samples are presented in Table 4. The statistical model presented in Equation 1 shows the relationship between the energy consumption intensity and the operating parameters.

$$
I=\frac{F_{r}^{0.695} \times D_{c}^{0.495} \times P_{s}^{0.3}}{10^{2.103}}
$$

In this Equation $\mathrm{Fr}$ is the feed rate $(\mathrm{cm} / \mathrm{min})$ of a workpiece, Dc is the Depth of cut ( $\mathrm{mm})$, Ps presents the Peripheral speed (rpm) and I is the energy consumption in Amperes.

The $\mathrm{F}$ and $\mathrm{t}$ tests were consequently used to validate the model and to control each of the independent varia- bles. The results of $\mathrm{F}$ and $\mathrm{t}$ tests are shown in Table 4 . The $\mathrm{F}$ value, which is obtained considering a confidence level of $99 \%$ (4.61) is less than that of the proposed model, therefore we can reject the hypothesis of zero, which states that there is no linear relationship between the energy consumption and the independent variables, and it can be concluded that at least one of the coefficients is not zero. After general control of a model with test $\mathrm{F}$, the meaning of each independent variable is controlled with test $t$. Using the $t$ test, we can examine the zero hypothesis for each coefficient of the independent variables. The $\mathrm{t}$ value of the distribution with a confidence level of $99 \%$ is 2.86 , while the $t$ values of the independent variables are higher than this amount so that, for the coefficients of the independent variables, we can reject the zero hypothesis. Another determination way of statistical models is using the scatterplot of the predicted and the real observed values. Perfect estimations have scatterplots with points, which are exactly on a straight line with a slope of 1. Figure 7 shows the scatterplot of the predicted values versus the observed ones. It is clear that the points are very close to the mentioned line and they are almost evenly distributed without showing a noticeable bias. Then it can be said that the introduced model has a high degree of accuracy with a high correlation between the predicted and the observed values.

Table 4: Statistical results of the model

\begin{tabular}{|c|c|c|c|c|c|c|c|}
\hline Independent variables & Coefficient & Standard error & $\mathbf{F}$ & Tabulated F & $\mathbf{T}$ & Tabulated $\mathbf{t}$ & $\mathbf{R}^{2}$ \\
\hline Constant & -2.103 & 0.223 & \multirow{4}{*}{$227 \cdot 33$} & \multirow{4}{*}{4.61} & -9.414 & \multirow{4}{*}{2.86} & \multirow{4}{*}{0.86} \\
\hline$F_{r}$ & 0.695 & 0.038 & & & 18.319 & & \\
\hline$D_{c}$ & 0.495 & 0.031 & & & $15 \cdot 75$ & & \\
\hline $\mathbf{P}_{\mathrm{s}}$ & 0.3 & 0.074 & & & -4.08 & & \\
\hline
\end{tabular}




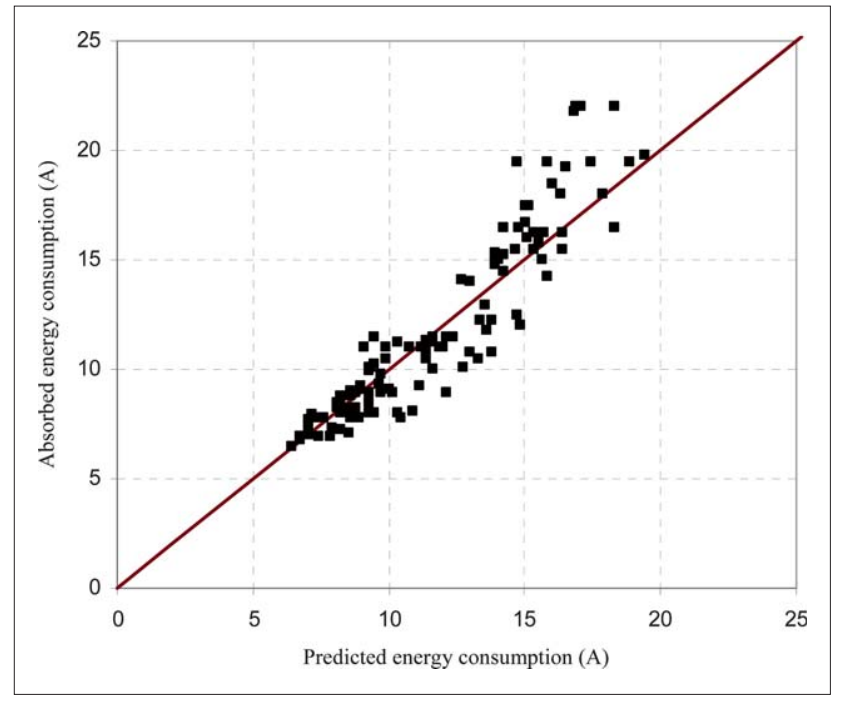

Figure 7: Scatterplot of the absorbed energy consumption versus the predicted values

\section{Conclusions}

Today, cutting discs are widely used in building stone factories. A full perception of the cutting devices and the effective cutting parameters are useful for designers to improve the speed of the process and to increase the production rate. Two of the most important factors of marketing are the cost and the quality of goods. Some of the most important factors affecting the cutting cost are repairing and maintenance costs of the cutting machines and the energy consumption rate. Typically, the production rate and the mentioned parameters are directly related. Therefore, using the best parameters for optimum production rate is essential. In this regard, we considered the energy consumption of the device for different operating parameters. The results of the study are summarized as follows:

1. The cutting depth and the feed rate have direct relationships with energy consumption. The reason can be searched in the cutting mechanism and the ease of chip formation.

2. Looking at the graphs of the energy consumption versus the feed rate and the depth of cut, the slope increases toward the higher values of these parameters. Energy consumption reaches its maximum points at a feed rate of 400 and a cutting depth of $35 \mathrm{~mm}$.

3. Using more than 120 samples tested at different operating conditions, a statistical model was developed to predict energy consumption. The results of the statistical tests ( $t$ and F) showed that the assigned coefficients of variables are correct. The scatterplot of the predicted and the observed values of energy consumption show a high correlation with no bias and reproduction of high and low values.
4. According to the studies, in a laboratory scale, with the depth of cut and feed rate increase, energy consumption per unit area of cut (the specific energy consumption) is close to its optimum value. However, the problem here is that by increasing these two parameters, the load on the device increases, it is obvious that by increasing the load on the device, in addition to increasing the cost of maintenance of the device, the vibration on the disk increases and the slots in the cutting direction become wider and the stone throw increases. In addition, in such a situation, the probability that diamonds emerge from the band due to the cutting force increases. Therefore, it is necessary to examine all the effective factors together in order to achieve an ideal cutting condition. To determine the best cutting condition, the model presented in this study can also help, along with the other models (wear and vibration prediction models) to help to achieve ideal cutting conditions.

Finally, the predicted model can only be applied to carbonate rocks. More studies must be conducted to check the validity of the obtained models for other types of rocks such as granite, syenite, gabbro, basalt, andesite, sandstone and onyx. Additionally, the effect of the type of disc should be studied.

\section{Reference}

Benavente, D., Garcia Del Cura, M.A., Bernabeu, A. and Ordonez, S. (2001): Quantification of salt weathering in porous stones using an experimental continuous partial immersion method. Engineering Geology, 59, 313-325.

Atici, U., Ersoy, A. (2009): Correlation of specific energy of cutting saws and drilling bits with rock brittleness and destruction energy. journal of materials processing technology, 209, 2602-2612.

Buyuksagis, I.S., Goktan, R.M. (2005): Investigation of marble machining performance using an instrumented blockcutter. Journal of Materials Processing Technology, 169, 258-262.

Buyuksagis, I.S. (2007): Effect of cutting mode on the sawability of granites using segmented circular diamond sawblade. Journal of Materials Processing Technology, 183, 399-406.

Clausen, R., Wang, C.Y., Meding, M. (1996): Characteristics of acoustic emission during single diamond scratching of granite. Industrial Diamond Review, 3, 96-9.

Engels, A. (2003): The role of Particles Per Carat in diamond tool behaviour, Industrial Diamond Review, 2, 39-45.

Ertingshausen, W. (1985): Wear processes in sawing hard stone, Industrial Diamond Review, 5, 254-258.

Ersoy, A., Atici, U. (2004): Performance characteristics of circular diamond saws in cutting different types of rocks. Diamond and Related Materials, 13, 22-37.

Gunaydin, O., Kahraman, S., Fener, M. (2004): Sawability prediction of carbonate rocks from brittleness indexes. 
The Journal of the Southern African Institute of Mining and Metallurgy, 104, 239-244.

Jennings, M., Wright, D.N., (1989): Guidelines for sawing stone. Industrial Diamond Review, 2, 70-75.

Kahraman, S., Fener, M., Gunaydin, O. (2004): Predicting the sawability of carbonate rocks using multiple curvilinear regression analysis. International Journal of Rock Mechanics \& Mining Sciences, 41, 1123-1131.

Konstanty, J. (2002): Theoretical analysis of srone sawing with diamonds. Journal of materials processing technology, 123, 146-154.

Konstanty, J. (1991): THE MATERIALS SCIENCE OF STONE SAWING. Industrial Diamond Review, 1, 27-31

Mikaeil, R., Ataei, M. and Yousefi, R. (2011a): Application of a fuzzy analytical hierarchy process to the prediction of vibration during rock sawing. Mining Science and Technology (China), 21(5), 611-619.

Mikaeil, R., Yousefi, R. and Ataei, M. (2011b): Sawability Ranking of Carbonate Rock Using Fuzzy Analytical Hierarchy Process and TOPSIS Approaches. Scientia Iranica, 18(5), 1106-1115.

Mikaeil, R., Ozcelik Y., Ataei M. and Yousefi R. (2011c): Correlation of Specific Ampere Draw with Rock Brittleness Indexes in Rock Sawing Process. Arch. Min. Sci., 56(4), 741-752.
Mikaeil, R., Ataei, M., Ghadernejad, S. and Sadegheslam, G. (2014): Predicting the relationship between system vibration with rock brittleness indexes in rock sawing process. Archives of Mining Sciences, 59(1), 139-153.

Mikaeil, R., Haghshenas, S.S., Haghshenas, S.S. and Ataei, M. (2016): Performance prediction of circular saw machine using imperialist competitive algorithm and fuzzy clustering technique. Neural Computing and Applications, 29(6), 283-292.

Polini,W.,Turchetta,S. (2007): Monitoring of diamond disk wear in stone cutting by means of force or acceleration sensors. Int. j.Adv Manuf Technol, 35, 454-467.

Tonshoff, H.K, Hillmann-Apmann, H., Asche, J. (2002): Diamond tools in stone and civil engineering industry: cutting principles, wear and applications. Diamond and Related Materials, 11, 736-741.

$\mathrm{Xu}, \mathrm{X}$. (1999): Friction studies on the process in circular sawing of granites. Tribology Letters, 7, 221-227.

$\mathrm{Xu}, \mathrm{X}$., Li, Y., Malkin, S. (2001): Forces and energy in circular sawing and grinding of granite. Journal of Manufacturing Science and Engineering, 123, 13-22.

$\mathrm{Xu}, \mathrm{X} ., \mathrm{Li}, \mathrm{Y}$. and Yu, Y. (2003): Force ratio in the circular sawing of granites with a diamond segmented blade. Journal of Materials Processing Technology, 139, 281-285.

\section{SAŽETAK}

\section{Istraživanje utroška energije kod rezanja arhitektonsko-građevnoga kamena}

U industriji arhitektonsko-građevnoga kamena važno je predvidjeti utrošak energije kod njegova rezanja. Utvrđivanje odnosa strojnih varijabli s tim utroškom važan je postupak. Konstruirani su ispitni, laboratorijski rezaći strojevi s mogućnošću promjene radnih varijabli. Prikupljeni rezultati statistički su analizirani usporedbom s potrošnjom energije. Testiranje je načinjeno na sedam uzoraka karbonatnih stijena, uz različite vrijednosti dubine zarezivanja, jakosti i brzine. Tako je dobiven model utroška energije, postavljen u odnosu na svaku promatranu, nezavisnu varijablu. Statistička analiza načinjena je paketom SPSS. U njoj su primijenjeni t-test i F-test. Vrijednosti predviđene takvim modelom prikazane su dijagramom raspršenja. Rezultati su vrlo bliski linearnomu modelu predstavljenomu pravcem pod kutom od 45 stupnjeva. Takav model odlikuje se visokim stupnjem točnosti te korelacije između predviđenih i opaženih vrijednosti. Stoga on može biti korišten za izračun utroška energije uz različite ulazne varijable.

\section{Ključne riječi:}

utrošak energije, brzina punjenja, periferna brzina, dubina urezivanja, SPSS, arhitektonsko-građevni kamen

\section{Authors' contribution}

Reza Mikaeil (Associate Professor): initializing the idea, completing literature review and participating in all work stages such providing rock samples, running experimental tests and data analysis. Babak Sohrabian (Assistant Professor): executing experimental tests, data analysis and test of its accuracy and helping with field work. Mohammad Ataei (Full Professor): managing the whole process and supervising it from the beginning to the end. 